\title{
TATA KELOLA PENYELENGGARAAN PEMERINTAH DESA
}

\author{
Wijoko Lestariono \\ Fakultas IImu Sosial dan IImu Politik Universitas Palangka Raya \\ (email: wijikolestariono@gmail.com) \\ Linda Susanti \\ Fakultas IImu Sosial dan IImu Politik Universitas PGRI Palangka Raya
}

\begin{abstract}
Abstrak
Penelitian ini mengkaji Tata Kelola Penyelenggaraan Pemerintahan Desa (Studi Pemerintahan Desa Mekar Jaya Kecamatan Parenggean). Masalah penelitian ini berbicara Tata Kelola Penyelenggaraan Pemerintahan Desa di Desa Mekar Jaya dalam daya upaya penyelenggaraan pemerintahan desa bersama masyarakat diantaranya dalam hal ini pembangunan desa dan peningkatan sumber daya manusia. Berdasarkan undang-undang No.6 Tahun 2014 tentang desa, maka setiap desa diharapkan dapat melakukan perubahan tata kelola Desa baik dari segi pembangunan, struktur lembaga, pemberdayaan masyarakat dan proses pemerintahan dalam mewujudkan pemerintahan yang efektif. Rumusan masalah dalam penelitian ini yaitu bagaimana penerapan undang-undang No.6 Tahun 2014 tentang desa dan faktorfaktor terbitnya undang-undang No.6 Tahun 2014 tentang desa

Jenis penelitian menggunakan tipe penelitian kualitatif dengan analisi deskriptif. Sumber data yang diperoleh yaitu data primer dan data sekunder. Metode pengumpulan data dilakukan melalui observasi dan wawancara dan melalui kajian literatur pustaka. Teknik analisis data yang digunakan yaitu teknik analisa secara kualitatif yang selanjutnya disajikan secara deskriptif. Adapun kerangka konseptual dan teoritis yang penulis gunakan yaitu teori implementasi kebijakan, teori otonomi daerah dan teori good governance.

Hasil penelitian menunjukkan bahwa untuk mewujudkan pemerintahan yang baik dalam hal ini pada Tata Kelola Penyelenggaraan Pemerintah desa pada penerapan dan faktor-faktor terbitnya UU No.6 Tahun 2014 ada 10 prinsip yang harus diterapkan, empat diantaranya yaitu 1. Pengawasan 2. Daya Tanggap 3. Transparansi 4. Partisipasi. Faktor-faktor yang mendukung penerapan UU No.6 tahun 2014 di desa majannang diantaranya 1. Kondisi lingkungan; 2.SDM aparatur; 3. Masyarakat
\end{abstract}

Kata kunci : Tata Kelola Desa, Penyelenggaraan Pemerintah Desa 
Pendahuluan

Dalam sejarah pengaturan Desa, telah ditetapkan beberapa pengaturan tentang Desa, yaitu Undang-Undang Nomor 22 Tahun 1948 tentang Pokok Pemerintahan Daerah, Undang-Undang Nomor 1 Tahun 1957 tentang PokokPokok Pemerintahan Daerah, UndangUndang Nomor 18 Tahun 1965 tentang Pokok-Pokok Pemerintahan Daerah, Undang-Undang Nomor 19 Tahun 1965 tentang Desa Praja Sebagai Bentuk Peralihan Untuk Mempercepat Terwujudnya Daerah Tingkat III di Seluruh Wilayah Republik Indonesia, Undang-Undang Nomor 5 Tahun 1974 tentang Pokok-Pokok Pemerintahan di Daerah, Undang-Undang Nomor 5 Tahun 1979 tentang Pemerintahan Desa, UndangUndang Nomor 22 Tahun 1999 tentang Pemerintahan Daerah, dan terakhir dengan Undang-Undang Nomor 32 Tahun 2004 tentang Pemerintahan Daerah.

Dalam pelaksanaannya, pengaturan mengenai Desa tersebut belum dapat mewadahi segala kepentingan dan kebutuhan masyarakat Desa yang hingga saat ini sudah berjumlah sekitar 73.000 (tujuh puluh tiga ribu) Desa dan sekitar 8.000 (delapan ribu) kelurahan. Selain itu, pelaksanaan pengaturan Desa yang selama ini berlaku sudah tidak sesuai lagi dengan perkembangan zaman, terutama antara lain menyangkut kedudukan masyarakat hukum adat, demokratisasi, keberagaman, partisipasi masyarakat, serta kemajuan dan pemerataan pembangunan sehingga menimbulkan kesenjangan antarwilayah, kemiskinan, dan masalah sosial budaya yang dapat mengganggu keutuhan Negara Kesatuan Republik Indonesia.

Pemerintah pada tanggal 15 Januari 2014 telah menetapkan UU No. 6 Tahun 2014 tentang Desa. Dalam konsideran UU tersebut diisampaikan bahwa Desa memiliki hak asal usul dan hak tradisional dalam mengatur dan mengurus kepentingan masyarakat setempat dan berperan mewujudkan citacita kemerdekaan berdasarkan UndangUndang Dasar Negara Republik Indonesia Tahun 1945. Dalam perjalanan ketatanegaraan Republik Indonesia, Desa telah berkembang dalam berbagai bentuk sehingga perlu dilindungi dan diberdayakan agar menjadi kuat, maju, mandiri, dan demokratis sehingga dapat menciptakan landasan yang kuat dalam melaksanakan pemerintahan dan pembangunan menuju masyarakat yang adil, makmur, dan sejahtera. Jika kita pahami dari konstruksi hukum terhadap struktur pemerintahan desa, sebenarnya masih menggunakan konstruksi hukum yang diterapkan selama ini. Hal ini dapat kita telusuri dari teks hukum pada pasal 1 UU No 6 Tahun 2014 yang menyatakan, bahwa Pemerintahan Desa adalah penyelenggaraan urusan pemerintahan dan kepentingan masyarakat setempat dalam sistem pemerintahan Negara Kesatuan Republik Indonesia.

Suatu fakta yang nyata bahwa di beberapa wilayah tertentu di Indonesia, yaitu di pulau jawa penggunaaan tanah di pertanian dilakukan secara sangat intensif akibat kerapatan penduduk yang tinggi. Sementara itu, di beberapa wilayah lain diluar pulau jawa tanahnya hampir tidak terjamah manusia karena penduduknya jarang / karena wilayahnya hampir tidak berpenduduk.

Daya upaya penyelenggaraan pemerintah desa bersama masyarakat salah satunya dengan melaksanakan Pembangunan Desa. Dalam hal ini pembangunan desa hanya akan berhasil, apabila dilaksanakan dengan suatu pola,

\section{Jurnal Sociopolitico}


Sistem dan mekanisme yang tepat. Mekanisme pembangunan desa adalah suatu proses perpaduan antara dua kelompok utama, yaitu: berbagai kegiatan pemerintah dan kegiatan partisipasi masyarakat.

1. Berbagai kegiatan pemerintah

Program - program pembangunan yang dilaksanakan oleh berbagai departemen dan lembaga - lembaga non departemen, baik berupa program sektoral maupun program khusus, serta program pemerintah daerah adalah merupakan kelompok kegiatan pemerintah dimana inisiatif, perencanaan dan pembiayaannya bersumber dari atas menurut bidang dan tanggung jawab masing-masing. Sehubungan dengan adanya landasan hukum dan perundang-undangan tersebut maka wewenang, tugas dan kewajiban kepala wilayah, khususnya camat menjadi besar dan luas dalam menyelenggarakan pemerintahan desa. (Pudjiwat Sajogyo 1996)

Berbagai kegiatan pemerintahan desa Mekar Jaya pada penyelenggaraan perencanaan desa terdiri dari 1. Fasilitas penyusunan RPJMDES 2019-2023, 2. Penyelenggaraan pendapatan Desa, 3. Fasilitas pendataan profil desa, 4. Sarana dan prasarana kantor Desa, 5. pembuatan drainase jalan 6. Pembinaan PKK Desa, 7. pembinaan konsep posiandu, 8. pembinaan karang taruna, 9. pemberdayaan masyarakat, 10. Peningkatan kapasitas kepala desa dan aparat, 11. peningkatan kapasitas kelompok tani, 12. peningkatan kapasitas remaja masjid.

2. Berbagai kegiatan partisipasi masyarakat

Kegiatan - kegiatan partisipasi masyarakat yang tumbuh dari bawah sebagai inisiatif dan kreasi yang lahir dari rasa kesadaran dan tanggung jawab masyarakat mutlak perlu, sesuai dengan hakekat pembangunan desa yang pada prinsipnya dilakukan oleh masyarakat sendiri, dari dan untuk masyarakat dengan pengarahan, bimbingan , pembinaan , bantuan dan pengawasan dari pemerintah.

"Kepala desa menjalankan hak, wewenang dan kewajiban pimpinan pemerintahan desa yaitu menyelenggarakan rumah tangganya sendiri dan merupakan penyelenggara dan penanggung jawab utama di bidang pemerintahan, pembangunan dan kemasyarakatan dalam rangka penyelenggaraaan urusan pemerintahan desa, urusan pemerintahan umum termasuk pembinaan ketentraman dan ketertiban sesuai dengan peraturan perundang-undangan yang berlaku dan menumbuhkan serta mengembangkan jiwa gotong royong masyarakat sebagai sendi utama pemerintahan desa" (Pudjiwat Sajogyo 1996).

Berdasarkan Keadaan permukaan bumi di pedesaan sebuah desa terletak di dataran, diperbukitan, di sebuah gunung, atau mungkin di tepi laut.

1. Dataran

Desa - desa di daratan mempunyai berbagai macam topografi. Karena letaknya di gunung atau di dataran, topografi desa dapat berupa lereng yang terjal atau datar bergelombang. Selain dataran dan gunung, di daratan terdapat juga bukit, plato, lembah, dataran banjir, serta delta (pulau kecil) di muara sungai. Tiap satuan daratan mempunyai potensi yang berbeda sehingga tanaman di gunung berlainan jenisnya dengan tanaman di dataran. Selain itu, bentang-budaya tiap kawasan juga berbeda disebabkan keadaan topografi, flora dan fauna, serta

\section{Jurnal Sociopolitico}


lingkungan binaannya, yaitu pola perkampungan dengan tanah pertaniannya yang menyangkut sawah, ladang, kolam, perkebunan, hutan, dan lain-lain. (Johara T. Jayadinata, 2006).

2. Pantai dan Laut

Kehidupan sosial - ekonomi desadesa yang terletak di tepi laut banyak di pengaruhi oleh laut. Selain bertani, pekerjaan penduduk desa di tepi pesisir, umumnya, menangkap ikan dilaut.

Undang-undang No.6 Tahun 2014 tentang desa, maka setiap desa diharapkan dapat melakukan perubahan tata kelola Desa baik dari segi pembangunan, struktur lembaga, pemberdayaan masyarakat dan proses pemerintahan dalam mewujudkan pemerintahan yang efektif. Sebelum berlakunya Undang-undang No. 6 Tahun 2014 dari segi pembanguan, anggaran perencanaan pembanguan tidak melibatkan banyak unsur masyarakat dan setelah adanya Undang-undang No 6 Tahun 2014 anggaran perencanaan pembangunan sudah melibatkan banyak unsur masyarakat dan Sebelum berlakunya Undang-undang No.6 Tahun 2014 dari segi struktur lembaga yang ada yaitu Kaur pemerintahan, Kaur umum dan Kaur pembangunan tetapi setelah adanya Undang-undang No.6 Tahun 2016 berlaku struktur lembaga menanbah struktrur lembaga menjadi dua yaitu Kasi Pemberdayaan dan Kasi keuangan.

Sebelum berlakunya Undangundang No 6 Tahun 2014 dari segi proses Pemerintahan yang mewujudkan pemerintahan yang efektif, kelembagaankelembagaan seperti BPD, KPMD, Ketua RT belum terlalu memegang aktif peranan didalamnya tetapi setelah adanya Undangundang No. 6 Tahun 2014 kelembagaankelembagaan seperti BPD, KPMD dan Ketua RT sudah mempunyai peran yang sangat aktif didalamnya karna tanpa persetujuannya maka program yang akan dilaksanakan tidak dapat terlaksana, Undang-undang No.6 Tahun 2104 juga mencakup pemerintahan Desa yang professional, efisien, dan efektif terbuka serta bertanggungjawab terhadap masyarakat.

Undang-undang yang mencakup Desa ini juga memuat substansi pengaturan mengenai pembangunan, pemerintah Desa, lembaga kemasyarakatan dan pemberdayaan masyarakat, diharapkan dapat menjawab berbagai permasalahan di Desa tersebut. Dilihat pada tata kelola penyelenggaraan pemerintah Desa di Desa Mekar Jaya Kecamatan Parenggean beberapa sudah berjalan seperti pembangunan posyandu akan tetapi pelaksanaan penyelenggaraan pemerintah Desa belum dijalankan sesuai UU. No.6 Tahun 2014 tentang Desa sehingga tata kelola penyelenggaraan pemerintahan Desa belum dilaksanakan tentang undang-undang tersebut, contohnya rekrutmen aparat yang tidak memiliki standar operasional prosedur tentang cara dan teknis merekrut sehingga belum terlaksana sampai sekarang dan hal lainnya pemilihan kepala desa belum terlaksana selama 2 tahun. Fenomena lainnya adalah belum transparannya penggunaan anggaran desa dan pengelolaan fisik infrastruktur berdasarkan uu No.6 Tahun 2014.

\section{Metode Penelitian}

Penelitian kualitatif merupakan metode untuk mengeksplorasi dan memahami makna yang oleh sejumlah individu dan atau sekelompok orang di anggap berasal dari masalah-masalah social atau kemanusiaan. Proses penelitian

\section{Jurnal Sociopolitico}


kualitatif ini melibatkan upaya - upaya penting, seperti mengajukan pertanyaan pertanyaan dan prosedur - prosedur mengumpulkan data yang spesifik dari para partisipan, menganalisis data secara induktif mulai dari tema-tema yang khusus ke tema-tema umum, dan menafsirkan makna data. Laporan akhir untuk penelitian ini memiliki struktur atau kerangka yang fleksibel. Siapa pun yang terlibat dalam bentuk penelitian ini harus menerapkan cara pandang penelitian yang bergaya induktif, berfokus terhadap makna individual, dan menerjemahkan kompleksitas suatu persoalan. (John W. Creswell, 2009)

Tujuan dari penelitian kualitatif ini adalah untuk membuat deskripsi, gambaran atau lukisan secara sistematis, factual mengenai fakta-fakta, sifat-sifat serta hubungan antara fenomena yang akan diselidiki maka metode penelitian ini digunakan untuk memberikan gambaran tentang implementasi kebijakan penyelenggaraan pemerintah desa berdasarkan UU no.6 Tahun 2014 (studi kasus: Desa Mekar Jaya Kecamatan Parenggean).

\section{Hasil dan Pembahasan}

\section{Penerapan UU No.6 Tahun 2014 tentang Desa}

Pada penerapan undang - undang No.6 tahun 2014 penulis akan membahas tata kelola penyelenggaraan pemerintah desa dengan menguraikan empat prinsip pemerintahan yang baik (Good Governance). Berikut ini keempat prinsip Good Governance tersebut terkait Tata kelola penyelenggaraan pemerintah desa dalam hal ini di desa Mekar Jaya diantaranya sebagai berikut:

\section{Pengawasan}

Suatu pengawasan yang dilaksanakan oleh orang atau badan yang ada didalam lingkungan unit lembaga atau organisasinya. bentuk pengawasan yang dilaksanakan di desa Mekar Jaya pada kegiatan sebelum kegiatan tersebut dilakukan, agar mampu mencegah terjadinya kegiatan yang melenceng. Contohnya: pengawasan yang dilakukan pemerintah untuk menangkal penyimpangan pelaksanaan keuangan yang berpotensi akan merugikan anggaran untuk desa tersebut. Tata kelola penyelenggaraan pemerintah pada penerapan UU No.6 Tahun 2014. Berkenaan dengan hal ini Sekcam Parenggean mengatakan:

"Setelah pengawasannya sudah berjalan sesuai dengan sistem, seluruh lembaga di desa Mekar Jaya sudah harus dilibatkan semua kedalam penyelenggaraan pemerintah desa bahkan penegakpenegak hukum seperti kejaksaan dan kepolisian sudah ikut turun tangan dalam memantau pengawasan"(hasil wawancara dengan Sekcam)

Berdasarkan pernyataan diatas, keterlibatan seluruh lembaga untuk turun melihat dan menilai kondisi desa beserta tata kelola pemerintahan desa dengan adanya kerja sama antar lembaga sehingga pada penerapan Undang - Undang tersebut sudah ada anggaran pengawasan reses_Nya seperti Badan Permusyawaratan Desa (BPD).

Penyelenggaraan pemerintahan desa di desa Mekar Jaya tersebut pihak pengawasannya, pemerintah desa sudah mampu bertanggung jawab sebab sudah

\section{Jurnal Sociopolitico}


memiliki anggaran tersendiri, dapat disimpulkan bahwa bentuk pengawasannya ada 2 yaitu dalam bentuk laporan secara tertulis dan melakukan kunjungan lapangan. Dalam kerja sama yang dilakukan oleh masyarakat bersama dengan lembaga - lembaga Desa. Kelembagaan di desa Mekar Jaya terbagi atas dua yaitu lembaga pemerintahan dan lembaga kemasyarakatan.

Lembaga pemerintahan adalah sistem aturan atau proses yang terstruktur, yang digunakan untuk menyelenggarakan pemerintah daerah. Sistem aturan ini lalu dikonkritkan menjadi organisasi. (Hanif Nurcholis, 2007) Di desa Mekar Jaya di lembaga pemerintahan jumlah aparat pemerintah desa / kelurahan sebanyak 9 orang yang terdiri dari kepala desa / lurah, sekretaris desa, kepala urusan pemerintahan, kepala urusan pembangunan, dan kepala urusan umum.

Lembaga kemasyarakatan pada undang-undang no.6 tahun 2014 pasal 94 ayat (1) merupakan waah partisipasi masyarakat Desa sebagai mitra pemerintah desa. Lembaga kemasyarakatan Desa bertugas melakukan pemberdayaan masyarakat desa, ikut serta merencanakan dan melaksanakan pembangunan, serta meningkatkan pelayanan masyarakat desa. Pelaksanaan program dan kegiatan yang bersumber dari pemerintah, pemerintah daerah provinsi, pemerintah daerah kabupaten / kota, dan lembaga nonpemerintah wajib memberdayakan lembaga kemasyarakatan yang sudah ada di desa.(Lis Sutinah, 2014)

2. Daya Tanggap

Tata kelola penyelenggaraan pemerintah desa pada penerapan UU No. 6 Tahun 2014 dalam mewujudkan pemerintahan yang baik pada prinsip daya tanggap muncullah suatu pertanyaan mengenai respon penyelenggara pemerintah Desa terhadap aspirasi masyarakat di Desa Mekar Jaya terkait UU No.6 Tahun 2014. Eko mengatakan bahwa:

"Dengan terbitnya UU No. 6 Tahun 2014 keterlibatan respon mulai dari tingkat $R W$ kemudian ketingkat musyawarah dusun kemudian dari musyawarah dusun dibawah ketingkat desa" (Wawancara dengan Eko Tokoh Pemuda)

Berdasarkan pernyataan diatas, pemerintah dalam hal ini sangat merespon inisiasi dan inisiatif - inisiatif mulai dari tingkat bawah sampai tingkat atas, dikarenakan ada beberapa rapat - rapat yang menetapkan unsur - unsur masyarakat, mulai dari RT juga sudah ada kepedulian dari pemerintah dengan memberikan intensif meskipun intensif yang diberikan pemerintah belum sesuai dengan yang seharusnya diterima oleh para lembaga rukun tetangga (RT) desa mekar jaya. Sebelum terbitnya undangundang no.6 tahun 2014 RT hanya mendapat gaji ketika adanya kegiatan pesta dan penjualan hewan, penerapan kebijakan UU No 6 Tahun 2014 pemerintah lebih memperhatikan RW dan PKK dan lembaga-lembaga masyarakat yang ada di desa mekar jaya sehingga itulah perbedaan yang sangat mencolok.

Pada pembahasan sebelumnya, pemenuhan untuk menuju pemerintahan yang baik salah satunya yaitu dengan pembentukan kualitas sumber daya manusia yang unggul. Sumber daya manusia merupakan faktor yang sangat penting yang tidak dapat dilepaskan dari sebuah organisasi. Klasifikasi sumber daya manusia di desa mekar jaya yang terdiri

\section{Jurnal Sociopolitico}


dari potensi sumber daya manusia, tingkat pendidikan, mata pencaharian pokok, dapat dilihat pada tabel dibawah ini:

Klasifikasi Potensi Sumber Daya Manusia Desa Mekar Jaya

\begin{tabular}{|l|l|l|}
\hline No & Jenis Kelamin & Jumlah \\
\hline 1 & Laki-laki & 1.247 \\
\hline 2 & Perempuan & 1.168 \\
\hline & Jumlah & 2.415 \\
\hline & Kepala Keluarga & 736 \\
\hline & Kepadatan & - \\
\hline
\end{tabular}

Sumber daya manusia tidak dapat dilepaskan dari peran dan kualitas lembaga. Dengan demikian dapat dikatakan bahwa keterlibatan lembaga juga sangat ikut berperan dalam peningkatan sumber daya manusia dimana dalam penyelenggaraan pemerintah desa akan berjalan efektif meskipun tidak diberlakukan Undang-Undang. Lembaga merupakan system yang kompleks yang mencangkup berbagai hal yang berhubungan dengan konsep sosial, psikologis, politik dan hukum. Yang dimaksudkan penulis, lembaga yang berhubungan dengan politik. Dimana suatu lembaga tersebut terlibat dalam proses tata kelola penyelenggara pemerintah Desa khusunya di Desa Mekar Jaya. Berkenaan dengan hal ini Keterlibatan Lembaga Desa Mekar Jaya ikut aktif dalam programprogram yang dijalankan oleh pemerintah Desa yang bertujuan untuk mewujudkan serta meningkatkan pemberdayaan masyarakat. Adapun yang dikemukakan oleh Muhaimin mengatakan:

"Bahwa dalam pemberdayaan masyarakat lembaga - lembaga yang ada misalnya BPD , LKMD, Kelompok Tani sangat berperan aktif dalam memotifasi masyarakat disetiap kegiatan yang ada didesa, misalnya dalam kegiatan gotong royong dan kegiatan pembangunan di desa" (Wawancara dengan Muhaimin)

Pendapat diatas, dapat dipahami bahwa keterlibatan lembaga diantaranya adalah LKMD dan kelompok tani. Oleh karena itu, selain dengan bertujuan untuk meningkatkan pemberdayaan masyarakat lembaga juga berperan dalam meningkatkan pembangunan yang ada salah satunya adalah LKMD.

LKMD adalah lembaga masyarakat di desa atau kelurahan yang tumbuh dari oleh untuk masyarakat dan merupakan wahana partisipasi masyarakat dalam pembangunan yang memadukan pelaksanaan berbagai kegiatan pemerintah dan prakarsa serta swadaya gotong royong masyarakat dalam segala aspek kehidupan dalam rangka mewujudkan Ketahanan Nasional, yang meliputi aspek-aspek ideology, politik, ekonomi, sosial budaya, agama dan pertahanan keamanan. LKMD membantu pemerintah membantu pemerintah desa dalam merencanakan, pelaksanaan dan pembangunan desa.

Penyelenggaraan pemerintahan Desa merupakan subsistem dari sistem penyelenggaraan pemerintahan. Sehingga desa memiliki kewenangan untuk mengatur dan mengurus kepentingan masyarakatnya. Undang - undang nomor 22 Tahun 1999 tentang pemerintahan Desa yang merupakan pengganti Undang undang Nomor 5 Tahun 1974 tentang pokok - pokok pemerintahan di Daerah dan Undang - undang nomor 5 tahun 1979 tentang pemerintahan Desa mengatur pula tentang Desa. Dalam Undang - Undang Nomor 22 Tahun 1999 menegaskan bahwa desa tidak lagi merupakan wilayah administratif, bahkan tidak lagi menjadi

\section{Jurnal Sociopolitico}


bawahan atau unsur pelaksanaan daerah, tetapi menjadi daerah yang istimewa dan bersifat mandiri yang berada dalam wilayah kabupaten sehingga setiap warga desa berhak berbicara atas kepentingan sendiri sesuai kondisi sosial budaya yang hidup di lingkungan masyarakatnya. (Widjaja, 2010)

Terkait dengan hal tersebut diatas, adapun tata kelola penyelenggaraan pemerintah Desa di Desa Mekar Jaya Kecamatan Parenggean Kabupaten Kotawaringin Timur berdasarkan Undang - Undang Nomor 6 Tahun 2014 yang dikemukakan oleh Mas Bayu selaku kelompok tani mengatakan :

"Setelah berlakunya Undang Undang Nomor 6 Tahun 2014 berbicara masalah peningkatan pertanian jelas ada perubahan. Seperti adanya jalur -jalur akses pertanian sudah mulai dibangun sedikit demi sedikit (jalanan tani dan irigasi) sehingga membantu memudahkan pekerjaan khususnya para petani yang ada di Desa Mekar Jaya."(hasil wawancara dengan Mas Bayu Tokoh Tani)

Sedangkan Seto selaku Kepala Desa mengatakan :

“ Dengan adanyan atau berlakunya Undang-undang No 6 Tahun 2014 maka kemajuan atau tingkat perkapita masyarakat Desa dan Kesejahteraan masyarakat makin meningkat dibanding sebelumnya."(hasil wawancara dengan Seto kepala desa)

Berdasarkan pendapat di atas, dapat dipahami tata kelola penyelengaraan pemerintah Desa bahwa dalam menjalankannya berdasarkan
Undang - Undang Nomor 6 Tahun 2014 terlihat adanya peningkatan kesejahteraan terhadap masyarakat serta masyarakat ikut andil dalam menilai perkembangan upaya penyelenggaraan pemerintah desa. Artinya, pemerintah desa mampu menjalankan tugasnya dengan melihat kepentingan masyarakat khususnya di Desa Mekar Jaya tersebut.

3. Tranfaransi

Transparansi sebagaimana dimaksud adalah adanya hubungan timbal balik antara pemerintah dan masyarakat guna memperoleh suatu informasi yang dibuat oleh pemerintah agar masyarakat dapat memperoleh informasi tersebut. Transparansi bermakna tersedianya informasi yang cukup akurat dan tepat waktu tentang kebijakan yang dikeluarkan. Dengan ketersediaan informasi seperti ini masyarakat didesa Mekar Jaya dapat ikut sekaligus mengawasi sehingga kebijakan yang muncul bisa memberikan hasil yang optimal bagi masyarakat serta mencegah terjadinya kecurangan dan manipulasi yang hanya akan menguntungkan salah satu kelompok masyarakat. Disamping itu, transparansi sangat dibutuhkan agar penyelenggaraan pemerintah desa dapat berjalan secara efektif. Sejalan dengan hal ini informan beranggapan mengenai bagaimana hubungan timbal balik antara masyarakat dan pemerintah penerapan terbitnya UU No.6 Tahun 2014 di desa Mekar Jaya, Arizal Bahri mengatakan bahwa :

"Sekarang dengan berlakunya UU No 6 Tahun 2014 sudah dilakukan sosialisasi dan bahkan ada beberapa pertemuan - pertemuan yang dilakukan untuk menyampaikan prongram dan aspirasi - aspirasi masyarakat yang dilakukan dimana setiap ada

\section{Jurnal Sociopolitico}


acara seperti di acara perkawian dan di masjid" (hasil wawancara dengan Arizal Bahri)

Berdasarkan pernyataan diatas, dapat dipahami bahwa adanya perbedaan yang mencolok antara sebelum dan sesudah berlakunya Undang - Undang No.6 Tahun 2104. Sosialisasi tersebut menciptakan keterlibatan masyarakat dalam tata kelola penyelenggaraan pemerintah desa di desa Mekar Jaya sesudah berlakunya Undang - Undang No. 6 Tahun 2014.

\section{Partisipasi}

Partisipasi adalah prinsip bahwa setiap orang memiliki hak untuk terlibat dalam pengambilan keputusan di setiap kegiatan penyelenggaraan pemerintahan. Keterlibatan dapat dilakukan secara langsung maupun tidak langsung. Oleh Karena itu, keterlibatan masyarakat sangat di dibutuhkan dalam memperkuat demokrasi.( Loina Lalolo, 2003)

Dengan keterlibatan masyarakat dalam tata kelola penyelenggaraan pemerintah Desa di Desa Mekar Jaya dimana pemerintah dianggap sebagai figur utama dalam masyarakat karena memiliki kelebihan dan kebanyakan anggota masyarakat dilingkungannya. Dalam masyarakat modern (saat ini), pemerintah harus mempunyai kecakapan, kemampuan, bertanggung jawab agar mampu menjalankan atau mengelola semua kegiatan desa yang akan diselenggarakan. Jadi, di desa Mekar Jaya sendiri berlakunya undang-undang No.6 Tahun 2014 dalam meningkatkan dan mewujudkan kesejahateraan masyarakat dengan memperbanyak menyelenggarakan pembangunan seperti pembentukan irigasi untuk para petani, pembangunan posyandu, musrembang, rencana kerja pembangunan, penetapan APBDS. Dengan adanya perencanaan oleh pemerintah desa Mekar Jaya Inilah yang menjadi tata kelola penyelenggaraan pemerinta desa di desa Mekar Jaya kecamatan Parenggean kabupaten Kotawaringin Timur.

Partisipasi masyarakat merupakan bagian yang tak terpisahkan dari pembangunan itu sendiri. Sehingga nantinya seluruh lapisan masyarakat akan memperoleh hak untuk menuntut atau mendapatkan bagian yang adil dari manfaat pembangunan.

Masyarakat Desa Mekar Jaya juga ikut andil dalam proses terlaksananya pembangunan dengan menyodorkan bantuan oleh karena itu, bantuan pembangunan Desa digunakan untuk pembangunan jalur irigasi dimana di desa Mekar Jaya wilayahnya terbilang wilayah yang memiliki lahan persawahan yang sangat luas, sehingga bantuan ini sangat menjadi prioritas, dalam rangka menggerakkan swadaya gotong royong masyarakat dengan mengikutsertakan semua lembaga yang ada di desa agar berfungsi, sehingga terjadi keserasian laju pembangunan di Desa Mekar Jaya.

Pembangunan adalah sebuah wacana besar yang multifaced - terdapat banyak wajah atau dimensi. Development, begitu istilah yang sering dipakai untuk pembangunan, bukan hanya berkaitan dengan pengembangan fisik atau sarana dan prasarana, melainkan juga nonfisik, seperti mentalitas, pandangan kolektif masyarakat, dan seterusnya. Sejak pembangunan menjadi panglima bagi kehidupanbernegara dan bermasyarakat pada awal tahun 1970-an, seperti biasa dirasakan bersama, geliat pembangunan terjadi dimana-mana. (Widjaja, 2010)

\section{Jurnal Sociopolitico}


Adapun hal yang dikemukakan oleh Sri mengenai tingkat pembangunan di Desa Mekar Jaya saat ini mengatakan :

"Tingkat pembangunan, dilaksanakan berdasarkan rencana kerja yang telah di sepakati bersama alur BPD di masyarakat mulai dari perencanaan dari tingkat bawah sampai ke tingkat atas ( $R W$, Dusun, Desa, Kecamatan)" (Wawancara dengan Sri Kasi Kesejahteraan)

Berdasarkan pendapat diatas, pembangunan yang dilaksanakan di Desa Mekar Jaya adanya komunikasi yang baik antara pemerintah dan masyarakat. Komunikasi tersebut memberikan hal yang cukup baik yang dapat memajukan dan meningkatkan tercapainya tujuan yang diinginkan oleh masyarakat setempat. Sehingga dengan adanya pengawasan anggaran tersebut sehingga pembangunan dapat berjalan di desa Mekar Jaya.

Tingkat partisipasi masyarakat sudah sangat tinggi seperti dalam bentuk gotong royong salah satunya membicarakan mengenai kegiatan pembangunan itu. Setiap pembangunan yang dilaksanakan oleh pemerintah masyarakat dilibatkan langsung baik dalam memberikan mmasukan dan ikut rapat maupun bentuk kinerja yang dilakukan oleh masyarakat didesa Mekar Jaya. Melihat begitu besarnya partisipasi masyarakat maka dengan hal ini tidak jauh dari penciptaan terjalinnya komunikasi yang baik antara masyarakat dan pemerintah.

Komunikasi adalah proses sosial dimana individu-individu menggunakan simbol-simbol untuk menciptakan dan menginterpretasikan makna dalam lingkungan mereka. Pandangan komunikasi juga mencakup komunikasi tatap muka maupun komunikasi dengan media. Dengan demikian, ada lima istilah kunci dalam perspektif komunikasi yaitu : Sosial, Proses, Symbol, Makna, Dan Lingkungan, Sama halnya seorang kepala desa dalam menjalankan sistem pemerintahan dalam suatu desa harus menciptakan komunikasi yang baik antar masyarakat maupun pihak-pihak yang bekerja di pemerntahan. Dalam pembahasan ini, juga berkaitan dengan yang dikemukakan oleh Zulkarnain mengenai komunikasi antara kecamatan dengan desa Mekar Jaya sehingga belum ada pemilihan kepala Desa sampai sekarang mengatakan bahwa :

"penyebab utama pemilihan kepala desa belum belum dilaksanakan adalah terkait masalah regulasi (perda) tentang pemilihan kepala desa yang terlambat disahkan jadi komunikasi tetap berjalan ketingkat kecamatan/kabupaten sampai saat ini"'( Wawancara Dengan Reza Tokoh Pemuda).

Berdasarkan pernyataan di atas, dapat disimpulkan bahwa Dalam rangka pelaksanaan pemilihan kepala Desa di Desa Mekar Jaya sampai saat ini masih dalam tahap perencanaan, sebab belum terlihat adanya kegiatan ataupun sosialisasi yang dilakukan oleh pemerintah Desa guna untuk memilih kembali kepala Desa.

Faktor - Faktor Terbitnya UU No.6 Tahun 2014 tentang Desa

Dalam tata kelola penyelenggaraan pemerintah desa dalam hal ini di desa Mekar Jaya, faktor - faktor UU No.6 Tahun 2014 dalam prinsip Good

\section{Jurnal Sociopolitico}


Governance penulis mengambil 4 (empat) bagian diantaranya sebagai berikut :

\section{Pengawasan}

Didefenisikan bahwa Pengawasan adalah suatu proses dalam menetapkan ukuran kinerja baik dalam pengambilan keputusan maupun tindakan guna mendukung pencapaian hasil yang diharapkan sesuai dengan kinerja yang telah ditetapkan. Langkah dalam menciptakan pemerintahan yang baik dalam suatu desa salah satunya dengan melakukan pengawasan terhadap pejabat publik agar sistem pemerintahan dapat dijalankan dengan sebaik-baiknya oleh penyelenggara pemerintah desa. Terkait dengan hal ini, pengawasan terhadap tata kelola penyelenggaraan pemerintah desa sebelum berlakunya UU No.6 tahun 2014 tidak berjalan efektif dikarenakan sistem penyelenggaraan pemerintahan yang dilaksanakan tidak memperhatikan kegiatan-kegiatan lain yang seharusnya dijalankan oleh aparat pemerintahan. Seperti hal yang dikemukakan oleh Abdul Hakim mengatakan :

“ Bentuk pengawasan pemerintahan desa sebelum UU No.6 Tahun 2014dalam konteks tata kelola pemerintahan hanya lebih berfokus pada pengawasan keuangan saja. Artinya, kegiatankegiatan yang lain tidak dalam bentuk pengawasan misalnya kegiatan sosial pembangunan, bentuk pengawasan hanya sekedar dilihat secara langsung tapi tidak dalam bentuk sebuah laporan tertulis"'(Wawancara dengan Bardiono).

Berdasarkan pernyataan diatas, dapat dipahami bahwa pengawasan yang dilaksanakan pemerintah desa hanya menfokuskan pada satu kegiatan saja sehingga tata kelola penyelenggaraan pemerintah desa di desa Mekar Jaya program-program tidak dijalankan secara merata. Pengawasan yang dilakukan yaitu pengawasan keuangan. Bentuk pengawasan dalam bentuk tertulis yang dimaksud adalah pengawasan pada anggaran pemerintah saja khususnya untuk melaksanakan pembangunan yang menggunakan dana.

Pemerintah daerah merupakan hasil pembentukan dan pengembangan pemerintah pusat yang bahkan dapat dihapus oleh pemerintah pusat melalui proses hukum. Keberadaan satuan pemerintah daerah adalah tergantung (dependent) dan di bawah (subordinat) pemerintah pusat. Walaupun demikian, penyelenggara pemerintah Indonesia tidak akan sepenuhnya didasarkan atas sentralisasi belaka.(Widjaja, 2005)

Begitu strategisnya kedudukan dan peran kelapa daerah dalam sistem pertahanan sehingga seorang kepala daerah harus menerapkan pola kegiatan dinamis, aktif, dan komunkatif, menerapkan pola kekuasaan yang tepat maupun pola perilaku kepemimpinan yang sesuai dengan tuntutan kebutuhan yang di pengaruhi oleh latar belakang individual masing-masing daerah. Dalam konteks pelaksanaan otonomi daerah, seorang kepala daerah dalam implementasi pola kepemimpinannya seharusnya tidak hanya berorientasi pada tuntunan untuk memperoleh kewenangan yang sebesarbesarnya, tanpa menghiraukan makna Otonomi Daerah itu sendiri yang lahir dari suatu kebutuhan akan efisiensi dan efektivitas manajemen penyelenggaraan pemerintahan yang bertujuan untuk memberi pelayanan yang lebih baik

\section{Jurnal Sociopolitico}


kepada masyarakat. Berkenaan dengan pembahasan tersebut, tata kelola penyelenggaraan pemerintah desa tentang proses kepala Desa di Desa Mekar Jaya dalam mengeluarkan kebijakan kebijakan Bardiono mengatakan:

"Proses kebijakan selalu dimulai dari bawah seperti dalam bentuk musyawarah tingkat dusun dan dilanjutkan ketingkat Desa dan seterusnya."(Wawancara dengan Bardiono ketua BPD).

Berdasarkan pendapat informan diatas, bahwa bentuk musyawarah yang dilakukan pemerintah desa dalam mengeluarkan kebijakan pada prinsipnya adalah cara agar sebuah kebijakan dapat mencapai tujuannya. Sehingga implementasi tersebut tidak hanya sebelah pihak sehingga kebijakan baik berupa program-program yang kemudian berwujud pada kegiatan-kegiatan yang dikeluarkan oleh pemerintah desa maka masyarakat desa Mekar Jaya akan mengetahui bentuk kebijakan itu sehingga dapat terjalin komunikasi maupun kerja sama yang baik antara pemerintah dan masyarakat.

Era otonomi daerah dan desentralisasi fiskal berimplikasi pada bertambahnya kewenangan Desa. Untuk melaksanakan kewenangan tersebut diperlukan pendanaan yang mencukupi. Sesuai dengan hakekat otonomi, secara bertahap desa dituntut untuk mengupayakan kemandirian fiskal. Salah satu inditator kemandirian desa adalah kemampuan untuk membiayai diri sendiri, sehingga otonomi tidak hanya berarti memiliki wilayah tetapi juga pengelolaan keuangan dan kewenangan-kewenangan yang bersifat pokok.
2. Daya Tanggap

Proses penyelenggaraan pemerintah desa tidak terlepas dari prinsip good governance yaitu prinsip daya tanggap. Daya tanggap adalah meningkatkan kepekaan para penyelenggaraan pemerintah terhadap aspirasi masyarakat tanpa terkecuali. Adapun pertanyaan yang diajukan penulis oleh informan tentang respon penyelenggara pemerintah desa terhadap aspirasi masyarakat di desa Mekar Jaya sebelum berlakunnya UU No. 6 Tahun 2014, Asiz mengatakan :

“ Sebelum UU No.6 Tahun 2014 keterlibatan masyarakat sangat kurang , ini dibuktikan bahwa dalam penyusunan rencana kerja pemerintah desa dilaksanakan secara internal (kantor) tanpa melibatkan unsur - unsur yang terkait seperti masyarakat padahal Masyarakat jangan menjadi asing dan atau terasing di daerahnya sendiri. Masyarakat harus menjadi tuan rumah dirumahnya sendiri" (Wawancara Dengan Asiz, Tokoh Pemuda).

Kendala yang dihadapi adalah kebutuhan akan sumber daya manusia, tetapi kita tidak boleh berdalih secara "klasik" bahwa kita belum siap dengan sumber daya manusia. Upaya untuk menanggulangi misalnya dengan cara memanfaatkan secara maksimal sumber daya manusia yang telah ada dengan pelatihan, pengiriman tenaga ke dalam dan ke luar negeri, bahkan sementara dapat meminta atau mendatangkan tenaga ahli asing dengan imbalan jasa sesuai dengan ketentuan yang lazim berlaku. Semua ini perlu penanganan yang serius dan sungguh - sungguh, secara terencana,

\section{Jurnal Sociopolitico}


terprogram, dan terjadwal dan skala prioritas sesuai dengan kebutuhan. (Widjaja , 2005) Kendala eksternal tampaknya masih terasa ketidakseriusan pusat dalam menerapkan otonomi daerah, seperti masih meragukan ketidaksiapan daerah menerima otonomi daerah masalah pendapatan asli daerah (PAD), dan SDM yang berkualitas.

Berikut hasil wawancara dengan informan mengenai upaya pemerintah desa Mekar Jaya dalam mengelola sumber daya manusia sebelum berlakunya undang undang nomor 6 tahun 2014. Bardiono mengatakan:

"Sebelum undang - undang No 6 Tahun 2014 upaya pemerintah desa dalam pengelolaan sumber daya manusia terbatas pada anggaran sesudah undang undang No 6 Tahun 2014 diberlakukan maka anggaran pengelolaan sumber daya manusia sudah ada dalam program pegelolaan sumber daya manusia didalam rencana kegiatan dalam APBDes dengan bentuk kegiatan pelatihan -pelatihan"(Wawancara dengan Bardiono ketua BPD).

Pada pernyataan diatas, upaya pemerintah desa dalam penyelenggaraan program - program desa juga harus memperhatikan sumberdaya manusia bukan hanya kegiatan-kegiatan yang menguntungkan pihak pejabat sebab ketika sumber daya manusia membaik bukankah tata kelola penyelenggaraan pemerintah desa dapat berjalan maksimal karena mendapat bantuan dari masyarakat.

Dewasa ini kalangan pengambil keputusan dibidang sumber daya manusia diharapkan agar mulai menyempurnakan segala hal yang berkaitan dengan kualifikasi atau persyaratan kemampuan sumber daya manusia untuk dapat lebih mampu mengemban tugas pekerjaan tertentu, dengan memanfaatkan "kompetensi" (Sedarmayanti, 2012).

3. Transparansi

Pada prinsip ketiga ini dalam good governance yaitu transparansi yang diartikan menciptakan kepercayaan timbal balik antara pemerintah dan masyarakat melalui penyediaan informasi dan menjamin kemudahan didalam memperoleh informasi. Transparansi dibangun atas dasar kebebasan arus informasi. Proses lembaga dan informasi secara langsung dapat diterima oleh mereka yang membutuhkan. informasi harus dapat dipahami dan dapat dipantau.

Masyarakat sangatlah berperan penting dalam struktur pemerintahan sebagaimana lazimnya suatu wilayah administratif maka pembentukan desa harus memenuhi syarat-syarat tertentu salah satunya adalah jumlah penduduk atau masyarakat. Jumlah masyarakat tidak menutup kemungkinan akan semakin bertambah sehingga dengan banyaknya jumlah penduduk memungkinkan masyarakat untuk ikut terlibat dalam penyelenggaraan pengelolaan pemerintah desa baik secara aktif maupun pasif. Tidak bisa dipungkiri bahwa Desa merupakan entitas pemerintahan yang strategis yang langsung berhubungan dengan masyarakat. Dengan pola hubungan antara pemerintah dan masyarakat sangat dekat. Berkaitan dengan prinsip transparansi yang menciptakan adanya timbal balik antara pemerintah dan masyarakat, muncullah argument dari informan mengenai upaya pemerintah dalam melakukan komunikasi dengan masyarakat agar masyarakat dapat mudah memperoleh informasi tentang program-program

\section{Jurnal Sociopolitico}


penyelenggaraan pemerintah Desa sebelum berlakunya UU No.6 Tahun 2014, Samuji mengatakan :

"Pemerintah desa sangat jarang melakukan sosialisasi disetiap daerah, setiap pelosok, hingga sampai pada tingkat kecamatan. Hingga kegiatan dikelola secara internal saja ditingkat desa. Informasi program pemerintah terkadang sudah berjalan barulah masyarakat mengetahuinya" (Wawancara dengan Samuji Sekertaris Desa).

Dapat dipahami, pernyataan diatas begitu berpengaruhnya suatu aturan dalam bentuk Undang-Undang. Ungkapan informan diatas berlawanan dengan makna sosialisasi itu sendiri dimana Sosialisasi adalah proses kebiasaan nilai dan aturan dalam suatu kelompok ataupun masyarakat.

Sejarah perjalanan Tata pemerintahan Daerah/Desa selama ini berubah-ubah seiring dengan dinamika kondisi dan situasi politik Nasional. Undang-undang No 5 Tahun 1974 dan undang-undang No 5 Tahun 1979 kurang memberikan kebebasan Daerah/Desa untuk mengatur dan mengurus rumah tangganya sendiri. Kenyataannya dengan berbagai undang - undang pemerintahan, desa di perlemah karena diambil beberapa penghasilannya dan hak wilayahnya. Undang - undang tentang desa ternyata melemahkan atau menghapuskan banyak unsur - unsur demokrasi demi keseragaman bentuk dan susunan pemerintahan desa. Demokrasi tidak lebih hanya sekadar masih menjadi impian dan slogan dalam retorika dan pelipur lara. Masyarakat desa tidak dapat memberdayakan dirinya dan bahkan semakin lemah dan tidak berdaya. Teruntuk dengan pembahasan ini hasil wawancara dengan saudara Agus mengenai sikap masyarakat melihat kondisi pemerintahan desa Mekar Jaya mengatakan:

"masyarakat yang terkesan pasif.
Artinya masyarakat desa
khususnya di Desa Mekar Jaya
belum mampu memberdayakan
dirinya bahkan memperjuangkan
hak-hak mereka"(Wawancara
dengan Agus, Tokoh Pemuda).

Pernyataan tersebut dipahami bahwa di Desa Mekar Jaya sumber daya manusia belum diperhatikan oleh pemerintah, padahal sumber daya manusia merupakan potensi yang ada dalam diri manusia untuk suatu keperluan baik pada bidang pekerjaan atau lainnya. Kurang diperhatikannya sumber daya manusia inilah yang menjadi faktor-fakor terbitnya UU No.6 Tahun 2014. Dewasa ini, perkembangan sumber daya manusia bukan sebagai sumber daya belaka sebab sudah menjadi modal bagi institusi maupun suatu organisasi.

4. Partisipasi

Partisipasi bisa bersifat individual atau kolektif, terorganisir atau spontan, mantap atau sporadik, secara damai atau dengan kekerasan, legal atau illegal, efektif atau tidak efektif. Tata kelola penyelenggaraan pemerintah desa pada prinsip partisipasi erat kaitanya dengan partisipasi politik. Patisipasi politik adalah kegiatan warga yang bertindak sebagai pribadi - pribadi, yang dimaksud untuk memengaruhi pembuatan keputusan oleh pemerintah. Anggota masyarakat yang berpartisipasi dalam proses politik, misalnya melalui pemberian suara atau kegiatan lain, terdorong oleh keyakinan

\section{Jurnal Sociopolitico}


bahwa melalui kegiatan bersama itu bahwa kepentingan mereka akan tersalur atau sekurang - kurangnya diperhatikan, bahwa mereka sedikit banyak dapat memengaruhi tindakan yang berwenang untuk membuat keputusan yang mengikat.( Miriam Budiardjo, 2008) Pada uraian prinsip partisipasi diatas, adapun yang dikemukakan oleh informan tentang partisipasi masyarakat dalam penyelenggaraan pemerintah desa di desa Mekar Jaya dalam hal ini kebijakankebijakan pemerintah, M. Saleh " mengatakan :

“ Terbitnya UU No.6 tahun 2014 tingkat partisipasi masyarakat mulai dari dulu hingga saat ini 2014 tingkat partisipasi masyarakat sangat tinggi" (Wawancara dengan M. Saleh Tokoh Agama).

Pada pernyataan diatas, disimpulkan bahwa begitu besarnya upaya masyarakat untuk ikut andil dalam tata kelola pemerintah desa meskipun tidak terikat dengan aturan-aturan yang mengharuskan masyarakat untuk melakukan suatu hal yang bukan menjadi tugasnya. Dengan kesadaran, kemampuan, ketulusan, dan kedisiplinan masyarakat didesa desa Mekar Jaya dapat meningkatkan serta menciptakan sesuatu yang baik khususnya pada peningkatan kualitas sumber daya manusia dalam fungsi-fungsinya guna mewujudkan pelayanan yang optimal bagi masyarakat yang mutlak sangat diperlukan. Optimalnya suatu pelayanan dilakukan dengan kinerja dan produktivitas organisasi maupun lembaga maupun partisipasi masyarakat yang sangat efektif dan efisien.

\section{Jurnal Sociopolitico}

Fakultas Ilmu Sosial dan Ilmu Politik

\section{Kesimpulan}

Tata Kelola Penyelenggaraan Pemerintah Desa di Desa Mekar Jaya, Dalam Tata kelola penyelenggaraan pemerintah Desa di desa Mekar Jaya dibagi kedalam dua bagian yaitu :

1. Pengawasan

Suatu pengawasan yang dilaksanakan oleh orang atau badan yang ada didalam lingkungan unit lembaga atau organisasinya. bentuk pengawasan yang dilaksanakan di desa Mekar Jaya pada kegiatan sebelum kegiatan tersebut dilakukan,agar mampu mencegah terjadinya kegiatan yang melenceng.

2. Daya Tanggap

Tata kelola penyelenggaraan pemerintah desa Sesudah berlakunya UU No. 6 Tahun 2014 dalam mewujudkan pemerintahan yang baik pada prinsip daya tanggap muncullah suatu pertanyaan mengenai respon penyelenggara pemerintah Desa terhadap aspirasi masyarakat di Desa Mekar Jaya pada penerapan UU No.6 Tahun 2014.

\section{Transparansi}

Ketersediaan informasi seperti ini masyarakat didesa Mekar Jaya dapat ikut sekaligus mengawasi sehingga kebijakan yang muncul bisa memberikan hasil yang optimal bagi masyarakat serta mencegah terjadinya kecurangan dan manipulasi yang hanya akan menguntungkan salah satu kelompok masyarakat.

\section{Partisipasi}

Partisipasi adalah prinsip bahwa setiap orang memiliki hak untuk terlibat dalam pengambilan keputusan di setiap kegiatan penyelenggaraan pemerintahan. Keterlibatan dapat dilakukan secara langsung maupun tidak langsung. Dengan keterlibatan masyarakat dalam tata kelola 
penyelenggaraan pemerintah Desa di Desa Mekar Jaya dimana pemerintah dianggap sebagai figur utama dalam masyarakat karena memiliki kelebihan dan kebanyakan anggota masyarakat dilingkungannya.

\section{Referensi}

Afrizal Ahmad Arizki, Kinerja Pemerintahan Desa Sebagai Penyedia Pelayanan Publik Di Desa Wringinpitu Kecamatan Mojowarno Kabupaten Jombang, jurnal Vol.1, No.1 (2014).

Beratha, Nyoman. Pembangunan Desa Berwawasan Lingkungan Jakarta: Bumi Aksara 1991

Budiardjo, Miriam. Dasar - Dasar Ilmu Politik, Jakarta : PT. Gramedia Pustaka Utama, 2008

Creswell. J, Research design pendekatan kualitatif, kuantitatif, dan Mixed, Yogyakarta : Pustaka belajar, 2009

Daryanto Arief dkk. Mепији Desa 2030 Yogyakarta : Percetakan Pohon Jakarta, 2011

Didik G. Suharto. "Penyelenggaraan Pemerintahan Desa Dalam Perspektif Desentralisasi Administratif Dan Desentralisasi Politik,jurnal Vol 4, No 3 (2012)

Dunn William, Pengantar Analisis Kebijakan Publik, Yogyakarta, Gadjah Mada University Press, 2003

Haris Samsuddin, Desentralisasi \& Otonomi Daerah, Jakarta, LIPI Press, Anggota Ikapi, 2003

Jayadinata Johara. "Pembangunan Desa Dalam Perencanaan, Bandung: Penerbit ITB, 2006

Kaloh. Kepemimpinan Kepala Daerah Pola Kegiatan, Kekuasaan, Dan
Perilaku Kepala Daerah Dalam Pelaksanaan Otonomi Daerah (Jakarta: Sinar Grafika, 2009

Lalolo, Loina. Prinsip Akuntabilitas, Transparansi, dan Partisipasi dalam Good Governance Jakarta : Badan Perencanaan Nasional, 2003

Nurcholis Hanif, Teori dan Praktik Pemerintahan Dan Otonomi Daerah Jakarta : Grasindo 2007

Novitasari Rika, Partisipasi Politik (Political Participation) Dan Perilaku Pemilih (Voters Behavior) Dalam Pemilihan Kepala Desa (Pilkades) Tahun 2013 Di Desa Ngunut Kecamatan Ngunut Kabupaten Tulungagung, jurnal Vol.1 No.1 (2014) 